\title{
13. EOLIAN TRANSPORT TO HOLE 595A FROM THE LATE CRETACEOUS THROUGH THE CENOZOIC ${ }^{1}$
}

\author{
C. T. Schramm and M. S. Leinen, University of Rhode Island ${ }^{2}$
}

\begin{abstract}
The quartz contents of sediments from Hole 595A, determined by X-ray diffractometry, serve as an indicator of eolian transport of terrigenous material to the central southern Pacific. The quartz contents are very small and, within limits of analytical resolution, vary only slightly from the Cretaceous to the present. However, the accumulation rate of the eolian quartz does change significantly. The quartz accumulation reflects the changing position of the site with respect to the terrigenous source areas and the variations in wind systems through time.
\end{abstract}

\section{INTRODUCTION}

Hole 595A in the south central Pacific, $23^{\circ} 49.34^{\prime} \mathrm{S}$, $165^{\circ} 31.62^{\prime} \mathrm{W}$, is far from land and, in its present position, receives terrigenous sediments solely via atmospheric transport (Thiede, 1979). Therefore, the downcore record of eolian quartz deposition in Hole 595A reflects atmospheric conditions since the Late Cretaceous. The percentage of eolian quartz in deep-sea sediments is a function of source, wind velocity and direction, aridity, and bottom transport (Leinen and Heath, 1981; Leinen, 1985). The biogenic sediment component is small in Hole 595A, consisting of few ichthyoliths. The total sedimentation rate is very low, averaging $28 \mathrm{~cm} / \mathrm{m}$.y. for the Cenozoic (Winfrey et al., this volume). This reveals a long record of eolian sedimentation, but one of low stratigraphic resolution.

Hole 595A lies just north of contours of high quartz concentrations in surface sediments east of Australia, originally mapped by Thiede (1979; Fig. 1). The high quartz concentrations east of Australia reflect the present position of the westerly winds. The broad zone of decreasing quartz concentration in surface sediments west of South America indicates the pattern of atmospheric transport of terrigenous materials via the southeast trade winds (Scheidegger and Krissek, 1982; Molina-Cruz and Price, 1977). Since Hole 595A is located near the confluence of the westerlies and the southeast trade winds, it may presently receive terrigenous material from both Australian and South American sources. Global climate has changed throughout the Cenozoic, altering the distribution of aridity and the position and intensity of wind systems (Kennett, 1977). In addition, changes in the relative positions of the Australian and Pacific plates affect the location of the terrigenous source area with respect to the wind belts. The temporal record of eolian sedimentation, then, reflects a combination of tectonic and climatic variation. Identifying the paleoposition and

\footnotetext{
${ }^{1}$ Menard, H. W., Natland, J., Jordan, T. M., Orcutt, J. A., et al., Init. Repts. DSDP, 91: Washington (U.S. Govt. Printing Office).

2 Address: Graduate School of Oceanography, University of Rhode Island, Narragansett, RI 02882-1197.
}

migration of the site clarifies the influence of tectonics on eolian sedimentation. Fluctuations that are not accounted for by tectonic considerations reflect climatic variation.

\section{METHODS}

The percentage of quartz in samples from Hole 595A was determined by X-ray diffractometry. Because the quartz concentrations were expected to be low, samples were treated initially with sodium dithionite buffered with sodium citrate to remove the amorphous iron and manganese oxides (as described in Jackson et al., 1973). These components dilute the eolian quartz signal and decrease the intensity of the diffracted $\mathrm{X}$ ray. The remaining sample was ground to a uniform grain size and a quantity of alumina, equal to one half the sample weight, was added as an internal standard. After firing the samples at $1000^{\circ} \mathrm{C}$ for $24 \mathrm{hr}$. to remove interferences caused by clay minerals (modified from Till and Spears, 1969), duplicate planchettes for each sample were scanned by X-ray diffractometer over the cristobalite, alumina, and quartz peaks $\left(21.4^{\circ} 2 \theta, 25.4^{\circ} 2 \theta\right.$, and $26.55^{\circ} 2 \theta$, respectively). The ratio of the peak area of quartz to that of alumina was converted to weight percent quartz using the weighting factor of Ellis (1972). The amorphous-free quartz contents (Table 1, Fig. 2) are an average of the two X-ray runs. Precision for X-ray diffraction determination of quartz content is $\pm 0.5 \%$.

\section{RESULTS}

The quartz contents in Hole 595A are low, ranging between 0.8 and $3.04 \%$ of the amorphous-free sediment, with a mean of $1.5 \%$. The remainder of the iron and manganese oxide-free sediment primarily consisted of fine clays. Considering the precision of measurement, there is very little statistically significant fluctuation in the percent quartz downcore. The one anomalously large value of $3.04 \%$ at $11.52 \mathrm{~m}$ departs from the mean value by a factor of two. It is unlikely that this value is caused by error in the analysis because replicate determinations of quartz content were within $0.66 \%$ of each other.

The resolution of the ichthyolith stratigraphy for this site (Winfrey et al., this volume) is poor and only broad time intervals were identified. Ichthyoliths are most concentrated in the upper $15 \mathrm{~m}$ of the core. Identification of actual stratigraphic boundaries was not possible because of the low sedimentation rate, sparse presence of ichthyoliths, and poor correlation to the established equatorial Pacific ichthyolith stratigraphy (Doyle et al., 1977). A gross stratigraphy was derived for this study by aver- 


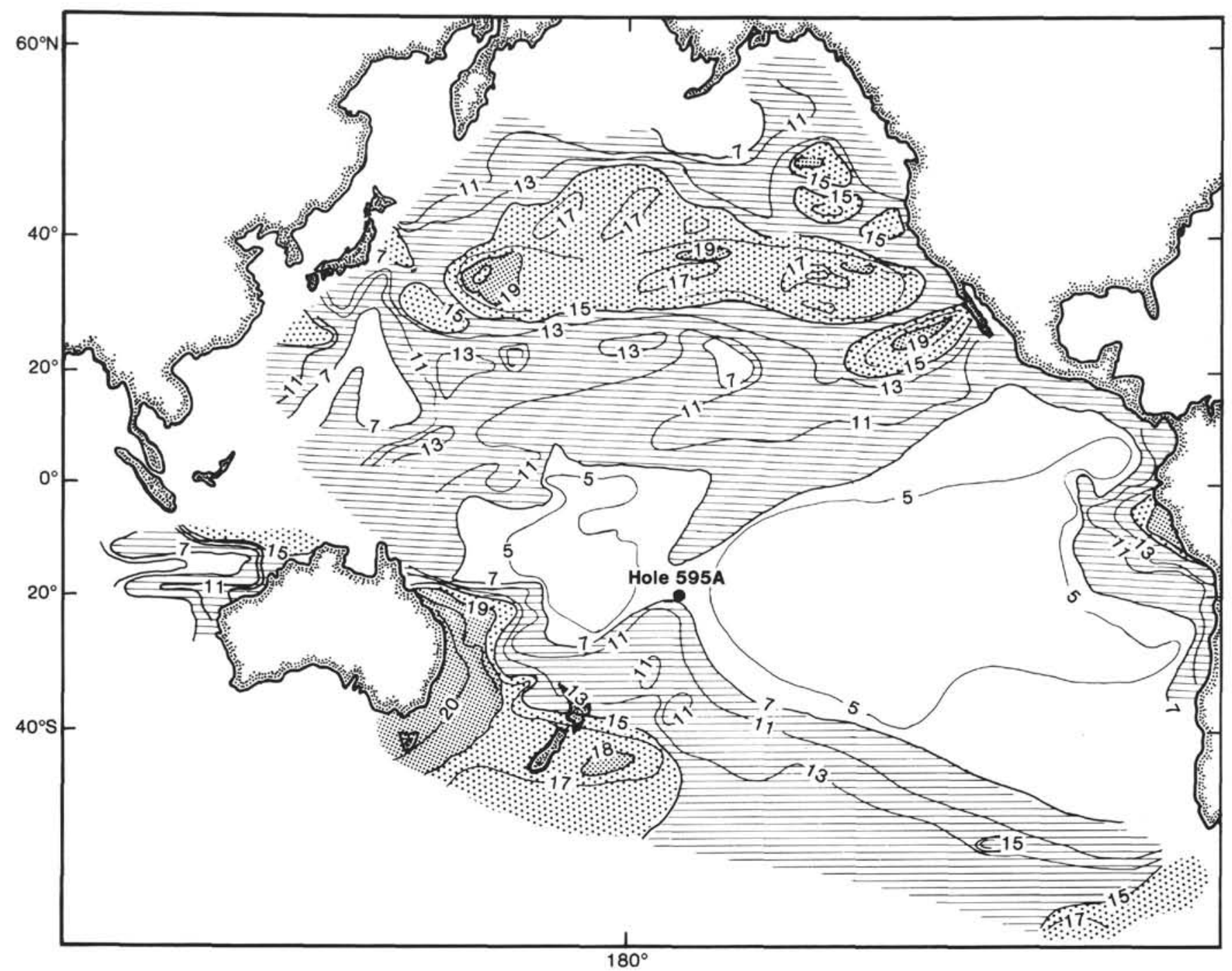

Figure 1. Location of Hole 595A within contours of quartz content in surface sediments (after Leinen et al., in press).

Table 1. Quartz content and sediment accumulation rates from Hole 595A.

\begin{tabular}{|c|c|c|c|c|c|}
\hline $\begin{array}{l}\text { Depth } \\
\text { (m) }\end{array}$ & $\begin{array}{c}\text { Age } \\
\text { (m.y.) }\end{array}$ & $\begin{array}{c}\text { Quartz (\%) } \\
\text { (amorph.- } \\
\text { free) }\end{array}$ & $\begin{array}{c}\text { Amorphous } \\
\text { material } \\
(\%)\end{array}$ & $\begin{array}{c}\text { Bulk } \\
\text { accumulation } \\
\text { rate } \\
\left(\mathrm{g} / \mathrm{cm}^{2} / \mathrm{m} . \mathrm{y} .\right)\end{array}$ & $\begin{array}{c}\text { Quartz } \\
\text { accumulation } \\
\text { rate } \\
\left(\mathrm{g} / \mathrm{cm}^{2} / \mathrm{m} . \mathrm{y} .\right)\end{array}$ \\
\hline 0.38 & 2.25 & 1.49 & 40.18 & 12.9 & 0.12 \\
\hline 1.88 & 11.12 & 1.71 & 63.31 & 12.6 & 0.08 \\
\hline 3.53 & 20.89 & 1.64 & 44.35 & 12.9 & 0.12 \\
\hline 5.03 & 27.91 & 1.48 & 26.80 & 20.5 & 0.22 \\
\hline 6.53 & 33.56 & 1.51 & 62.95 & 19.2 & 0.11 \\
\hline 11.52 & 52.34 & 3.04 & 57.78 & 21.1 & 0.27 \\
\hline 12.82 & 55.93 & 1.30 & 47.01 & 42.9 & 0.30 \\
\hline 14.31 & 58.39 & 1.75 & 62.87 & 43.7 & 0.29 \\
\hline 15.81 & 60.88 & 1.19 & 45.22 & 47.2 & 0.31 \\
\hline 22.50 & 71.93 & 1.55 & 41.42 & 47.1 & 0.42 \\
\hline 24.00 & 74.41 & 1.04 & 14.65 & 47.1 & 0.41 \\
\hline 25.54 & 76.95 & 1.47 & 0.0 & 50.3 & 0.73 \\
\hline 26.68 & 78.83 & 0.88 & 11.17 & 50.3 & 0.39 \\
\hline 29.69 & 83.80 & 1.10 & 34.61 & 50.3 & 0.35 \\
\hline
\end{tabular}

aging between samples deposited within a particular epoch (Table 2). There is much uncertainty in the stratigraphy, particularly in the older portion of the sedimentologic record. The lower half of Core 595A-3 is missing, leaving a gap of greater than $6 \mathrm{~m}$ between sampled intervals of Paleocene-Cretaceous sediment.

In spite of the poor stratigraphy, it is clear that there have been large changes in sedimentation rate over the time represented by the sediments. Therefore, even though the concentration of quartz in the sediment has remained nearly constant, its accumulation rate has not. Accumulation rates averaged over long periods of time (Table 1, Fig. 2) were calculated from the ichthyolith stratigraphy and the sediment dry-bulk density: accumulation rate $\left(\mathrm{g} / \mathrm{cm}^{2} / \mathrm{m} . \mathrm{y}\right.$. $)=$ sedimentation rate $(\mathrm{cm} /$ m.y.) $\times$ bulk density $\left(\mathrm{g} / \mathrm{cm}^{3}\right)$. The dry-bulk density measurements are from gravimetric data (Site 595 report, this volume). The quartz accumulation rates were calculated to adjust for the amorphous sediment removal and, therefore, reflect true mass fluxes of quartz. Accumulation rates of quartz are much higher in the Cretaceous and the Paleocene than in the later Cenozoic. Quartz accumu- 

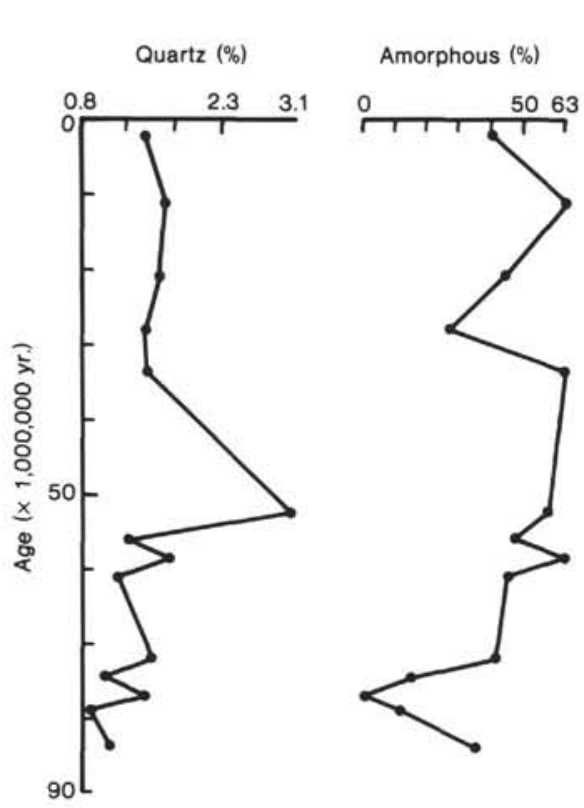

Quartz accumulation

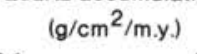

Figure 2. Downcore record of quartz and amorphous component contents and quartz accumulation rates.

Table 2. Gross stratigraphy for Hole 595A.

\begin{tabular}{lccc}
\hline & $\begin{array}{c}\text { Depth } \\
\text { interval } \\
(\mathrm{m})\end{array}$ & $\begin{array}{c}\text { Age } \\
(\mathrm{m} . \mathrm{y})\end{array}$ & $\begin{array}{c}\text { Average } \\
\text { sedimentation } \\
\text { rate } \\
(\mathrm{cm} / \mathrm{m} . \mathrm{y} .)\end{array}$ \\
\hline $\begin{array}{c}\text { Miocene and } \\
\text { younger }\end{array}$ & $0-4.15$ & $0-24.6$ & 17 \\
$\begin{array}{c}\text { Eocene and } \\
\text { Oligocene }\end{array}$ & $4.15-12.2$ & $24.6-54.9$ & 27 \\
$\begin{array}{c}\text { Paleocene } \\
\text { Cretaceous to } \\
\text { mid-Jurassic }\end{array}$ & $12.2-18.3$ & $54.9-65$ & 60 \\
\hline
\end{tabular}

lation decreased during the Eocene. Except for a slight increase in accumulation during the Miocene, quartz accumulation has remained consistently lower during the Neogene than in the Paleogene. The increase in quartz content at $11.52 \mathrm{~m}$, between the late Paleocene and early Eocene, does not appear as a maximum in the record of accumulation rates because the sedimentation rate in this interval is low.

\section{PALEOGEOGRAPHIC RECONSTRUCTION}

During the Late Cretaceous and the early Cenozoic, the southern Pacific was tectonically active. Gondwanaland fragmented as India traveled northward, colliding with the Asian Plate, and Australia broke away from Antarctica and moved to lower latitudes (Kennett, 1977). Antarctica provides a fixed reference point in most studies of the motion of Australia with respect to the Pacific Plate. Initial rifting of Australia from Antarctica commenced between $110-90$ m.y. at a very slow rate (Cande and Mutter, 1982). The spreading became more rapid during the early Eocene (Weissel and Hayes, 1972). The northwestward motion of the Pacific Plate during the Cenozoic is summarized in Molnar et al. (1975). In the Cretaceous the Pacific Plate was moving away from Ant- arctica at the Pacific-Antarctic Ridge at a relatively fast rate. Magnetic anomalies and trends of major fracture zones indicate that a change in spreading direction to a more east-west trend occurred in the early Eocene. Slower spreading rates during the early Eocene are associated with the reorganization of plates in the Southern Hemisphere (Rona and Richardson, 1978). From the Oligocene to the present, Pacific-Antarctic Ridge spreading rates have been more rapid.

As the Pacific and Australian plates moved, the position of the site with respect to source areas and wind systems changed. The paleoposition of Hole 595A in the Cretaceous and the late Paleocene was located using the paleogeographic reconstructions of Firstbrook et al. (1979), and poles of rotation for the Pacific Plate (Molnar et al., 1975; Fig. 3). Spreading rates of the Pacific-Antarctic Rise indicate that Hole 595A has moved approximately $4000 \mathrm{~km}$ northwest during the Cenozoic. However, the movement of Australia with respect to the $\mathrm{Pa}$ cific Plate on which Hole 595A is located suggests that only in the Late Cretaceous and early Paleocene was Australia in a position to be a major source of terrigenous material for this site.

\section{DISCUSSION}

Climate in the southwest Pacific has changed dramatically throughout the Cenozoic, largely in response to tectonic reorganization (Kennett, 1977). Temperatures have decreased since the Cretaceous, and the pole-to-equator temperature gradient has steepened (Shackleton and Kennett, 1975; Savin et al., 1975). Paleocene and Eocene climate was warmer and more equable than at present, although some periods of cooling have been deduced from the floral and faunal data for this interval (Haq and Lohmann, 1976; Wolfe, 1978). Very warm paleotemperatures occurred during the late Paleocene, early Eocene (Haq et al., 1977). At the end of the Eocene, as the Tasman Sea opened a connection between the southern Indian and Pacific oceans, Antarctic Bottom Water formation began, lowering bottom water temperatures approximately $4-6^{\circ} \mathrm{C}$ (Shackleton and Kennett, 1975). Sea ice began to accumulate around Antarctica, which increased the albedo in the Southern Hemisphere. This further enhanced thermal isolation of Antarctica. In the Oligocene, the initiation of Circum-Antarctic Current restricted pole-to-equator heat transport and increased the thermal gradient. Continued isolation of Antarctica and climatic feedback mechanisms resulted in glaciation during the mid-Miocene, which further intensified temperature gradients and is thought to have resulted in increased vigor of atmospheric and oceanic circulation (Kennett, 1977). In the late Pliocene, onset of Northern Hemisphere glaciation initiated a series of glacial/interglacial fluctuations, which also had a pronounced effect on wind position, intensity, and aridity in the Southern Hemisphere (Thiede, 1979).

Considering the magnitude of tectonic and climatic changes in the Cenozoic, it is remarkable that the quartz content at this site shows so little variation. It appears that this is primarily the result of the location of the core, which is far from a source area and outside of the 
zone of intense circulation in either the westerlies or the southeast trade winds. Either the site is so far from terrigenous sources that changes in the quartz content of the terrigenous eolian material with time have not affected it or the changes are smaller than the resolution of the X-ray technique and sampling density.

The only interval of increased quartz content in the sediment occurs at $11.52 \mathrm{~m}$ sub-bottom. The ichthyolith stratigraphy suggests that this is approximately late $\mathrm{Pa}$ leocene or early Eocene. There is no evidence for a more arid climate or more vigorous atmospheric circulation at this time, or for increased proximity of the site to a terrigenous source area. Hole 595A was located beneath the westerlies at this time, but Australia was located too far south to be a source of terrigenous material (Fig. 3). Since the increase of quartz in the sediment does not appear to be a function of either climate or source, it might reflect a change in bottom current activity. The tectonic reorganization of the Southern Hemisphere influenced the flow of bottom waters. Winnowing of the finer grained clays at this site would leave behind an increased concentration of the larger sized quartz grains. Grain-size analyses have not been done for this core, but the smear slide description (percentages of clays and silts) indicates that the percentage of clays was smallest at this interval, and the percentage of silt was $30 \%$, twice the average value (Hole 595A hole summary).

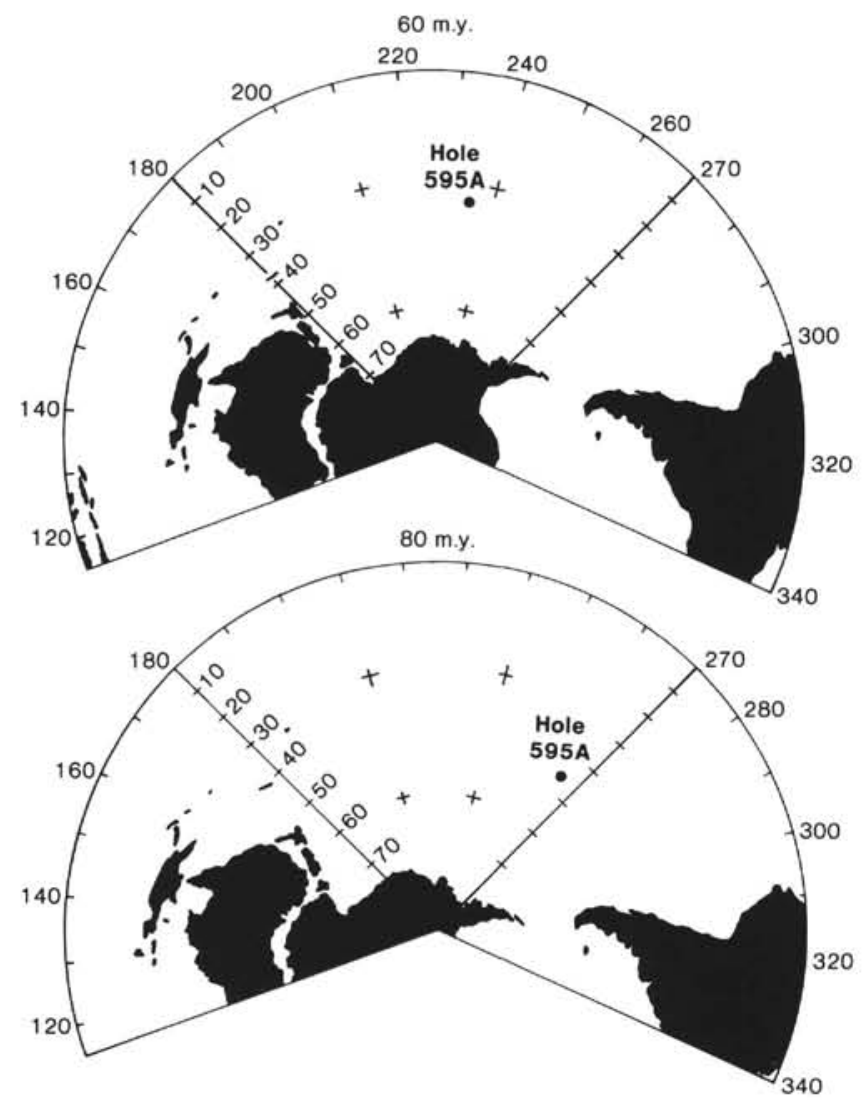

Figure 3. Paleoposition of Hole 595A at 60 and 80 m.y. ago (after Firstbrook et al., 1979; Molnar et al., 1975).
There is a clear change in quartz accumulation at the site over the last 90 m.y. There are no other published long-term records of eolian accumulation in the Southern Hemisphere with which to compare Hole 595A data. Interestingly, however, the Paleogene decrease of eolian quartz accumulation from higher Late Cretaceous levels that is evident in Hole 595A is also present in two Cenozoic records of eolian sedimentation in the North Pacific, in Hole 576A and LL44-GPC3 (Leinen, 1985; Rea et al., 1985). The paleogeographic reconstruction indicates that during the Paleocene and the Cretaceous, Hole 595A on the Pacific Plate was located southeast of its present position. Although this places the site closer to South America, it also locates Hole 595A underneath the core of the westerlies. Therefore, the higher accumulation rates during this time span may reflect erosion and transport of terrigenous material from an Australian source. Quartz accumulation decreased in the late Paleocene and Eocene as the site migrated north of Australia.

Paleogeographic reconstructions suggest that late in the Neogene, the northwestward motion of the Pacific Plate moved the site out from underneath the westerlies to a position beneath the trade winds. During the Neogene, while world climate, including that of Australia, became progressively more arid (Stein and Roberts, in press), increases in eolian sedimentation occurred in the north central Pacific (Leinen and Heath, 1981; Leinen, 1985; Rea et al., 1985; Janacek and Rea, 1983). In the southeast Pacific, increased grain size of eolian sediment from the middle Miocene is interpreted as reflecting wind intensification associated with Antarctic glaciation (Bloomstine and Rea, in press). Hole 595A sediments, however, reflect no increase in eolian quartz input during the late Neogene. This is most likely the result of the site location, north of the Australian source and distant from possible input of terrigenous material from South America via the trade winds. Unlike central North Pacific sediments, those from DSDP Hole 595A do not show a response to Northern Hemisphere glaciation. Such a response is also missing in eolian sedimentation in the southeast Pacific study of Bloomstine and Rea (in press).

\section{CONCLUSIONS}

The quartz content record in Hole 595A indicates relatively low input of terrigenous eolian material to the central southern Pacific. It is clear that there have been large changes in the rate of accumulation of eolian material, however, in spite of poor stratigraphic resolution. Accumulation rates were a factor of three greater during the Late Cretaceous and Paleocene than at present. This coincides with the Paleogene record of eolian sedimentation in the central North Pacific. Paleogeographic reconstructions suggest that the decrease in eolian sedimentation with time resulted from the rotation of the site out of a position where it could receive material transported from Australia, and later underneath the trade winds where it received only small amounts of material transported across the Pacific from South America. Be- 
cause of the large distance from sources of eolian material, the site has not recorded increases in eolian transport associated with late Cenozoic glacial age aridity and wind intensification as do many sites in the Pacific.

\section{ACKNOWLEDGMENTS}

We would like to thank Dave Rea for his thoughtful review of this manuscript and Mike Sundvik for assistance with the paleogeographic reconstruction.

\section{REFERENCES}

Bloomstine, M. K., and Rea, D. K., in press. Post-middle Oligocene history of eolian deposition from the southeast Pacific tradewinds. In Leinen, M., Rea, D. K., et al., Init. Repts. DSDP, 92: Washington (U.S. Govt. Printing Office).

Cande, S. C., and Mutter, J. C., 1982. A revised identification of the oldest sea-floor spreading anomalies between Australia and Antarctica. Earth Planet. Sci. Lett., 58:151-160.

Doyle, . S., Dunsworth, M. H., and Riedel, W. R., 1977. Reworking of ichthyoliths in eastern tropical Pacific sediments. Deep-Sea Res., 24:181-198.

Ellis, D. B., 1972. Holocene sediments of the South Atlantic Ocean: The calcite compensation depth and concentration of calcite, opal, and quartz [M.S. Thesis]. Oregon State University, Corvallis.

Firstbrook, P. L., Funnell, B. M., Hurley, A. M., and Smith, A. G., 1979. Paleoceanic Reconstructions, I60-0 Ma, Deep Sea Drilling Project publication.

Haq, B. U, and Lohmann, G. P., 1976. Early Cenozoic nannoplankton biogeography of the Atlantic Ocean. Mar. Micropaleontol., 1: 119-194.

Haq, B. U., Premoli Silva, I., and Lohmann, G. P., 1977. Calcareous planktonic paleobiogeographic evidence for major climatic fluctuations in the early Cenozoic Atlantic Ocean. J. Geophys. Res., 82: 3861-3876.

Jackson, M. L., Gillette, D. A., Danielson, E. F., Blifford, I. H., Bryson, R. A., and Syers, J. K., 1973. Global dustfall during the Quaternary as related to environments. Soil Sci., 116(3):135-145.

Janacek, T., and Rea, D. K., 1983. Eolian deposition in the North Pacific Ocean: Cenozoic history of atmospheric circulation. Geol. Soc. Am. Bull., 94:730-738.

Kennett, J. P., 1977. Cenozoic evolution of Antarctic glaciation, the Circum-Antarctic Ocean, and their impact on global paleoceanography. J. Geophys. Res., 82:3843-3859.

Leinen, M. S., 1985. Quartz content of northwest Pacific Hole 576A and implications for Cenozoic eolian transport. In Heath, G. R., Burckle, L. H., et al., Init. Repts. DSDP, 86: Washington (U.S. Govt. Printing Office), 581-588.
Leinen, M. S., Cwienk, D., Heath, G. R., Biscaye, P. E., Kolla, V., Thiede, J., Dauphin, J. P., in press. Distribution of biogenic silica and quartz in recent deep-sea sediments. Geology.

Leinen, M. S., and Heath, G. R., 1981. Sedimentary indicators of atmospheric activity in the Northern Hemisphere during the Cenozoic. Palaeogeogr., Palaeoclimatol., Palaeoecol., 36:1-21.

Molina-Cruz, A., and Price, P., 1977. Distribution of opal and quartz on the ocean floor of the subtropical southeastern Pacific. Geolo$g y, 5: 81-84$.

Molnar, P., Atwater, T., Mammerickx, J., and Smith, S. M., 1975. Magnetic anomalies bathymetry and the tectonic evolution of the South Pacific since the Late Cretaceous. Geophys. J. Roy. Astron. Soc., 40:383-420.

Rea, D. K., Leinen, M., and Janacek, T., 1985. A geological approach to the long-term history of atmospheric circulation. Science, 227: 721-725.

Rona, P. A., and Richardson, E. S., 1978. Early Cenozoic global plate reorganization. Earth Planet. Sci. Lett., 40(1):1-11.

Savin, S. M., Douglas, R. G., and Stehli, F. G., 1975. Tertiary marine paleotemperatures. Geol. Soc. Am. Bull., 86:1499-1510.

Scheidegger, K. F., and Krissek, L., 1982. Dispersal and deposition of eolian and fluvial sediments off Peru and Northern Chile. Geol. Soc. Am. Bull., 93:150-162.

Shackleton, N. J., and Kennett, J. P., 1975. Paleotemperature history of the Cenozoic and the initiation of Antarctic glaciation: Oxygen and carbon isotope analyses in DSDP Sites 277, 279, and 281. In Creager, J. S., Scholl, D. W., et al., Init. Repts. DSDP, 19: Washington (U.S. Govt. Printing Office), 743-755.

Stein, R., and Robert, C., 1985. Siliciclastic sediments at Sites 588, 590, and 591: Neogene and Paleogene evolution in the southwest Pacific and Australian climate. In von der Borch, C. C., Kennett, J. P., et al., Init. Repts. DSDP, 90: Washington (U.S. Govt. Printing Office), $1437-1458$.

Thiede, J., 1979. Wind regime over the Late Quaternary southwest Pacific Ocean. Geology, 7(5):259-263.

Till, R., and Spears, D. A., 1969. The determination of quartz in sedimentary rocks using an X-ray diffraction method. Clays Clay Min., 17:323-327.

Weissel, J. K., and Hayes, D. E., 1972. Magnetic anomalies in the southwest Indian Ocean. Antarctic Oceanology II: The Australian-New Zealand Sector, Antarctic Res. Ser., 19:165-196.

Wolfe, J. A., 1978. A paleobotanical interpretation of Tertiary climates in the Northern Hemisphere. Am. Sci., 66:694-703.

Date of Initial Receipt: 7 November 1984

Date of Acceptance: 22 October 1985 